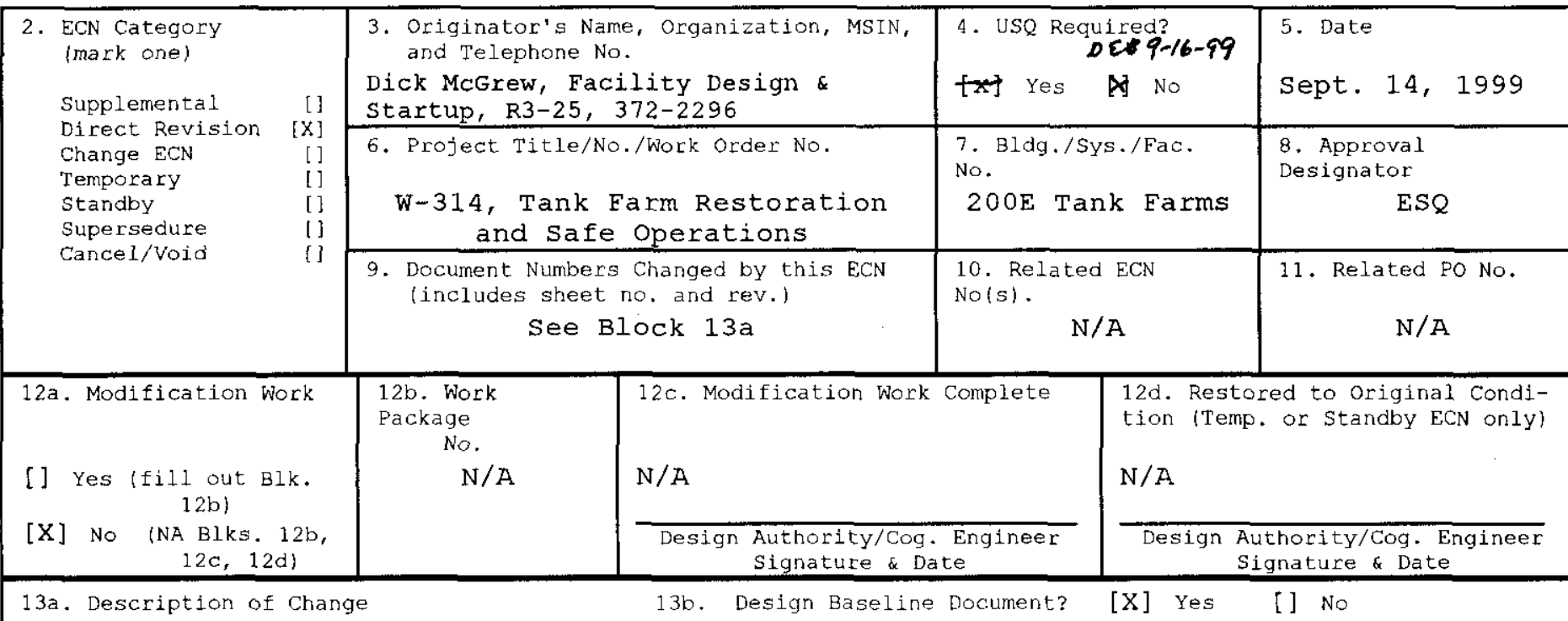

Block 9 continuation:

1. HNF-SD-W314-TI-007, Rev. 1, Project Design Concept-Transfer Piping

13a. Description of Change: This revision, HNF-SD-W314-TI-007, Rev 2, Supersedes Rev. 1. It incorporates all applicable ECN's associated with Rev. 1. This revision also adds/redefines specific concepts and requirements identified during the design implementation of the HNF-2500 report. The changes from Rev.1 are identified by utilizing a bold/strike-out text format.

14 a. Justification (mark one)

Criteria Change [X] Design Improvement [] Environmental [] Facility Deactivation [] As-Found [] Facilitate Const [] Const. Error/Omission [] Design Error/Omission []

$14 \mathrm{~b}$. Justification Details

This change is required to document the actual design specification changes needed for implementation of the HNF-2500 report and review comments. "This modification will not 'Mege collective dose since it has no impact on radiological sources, contamination control, or shielding." The changes made by this ECN, described in the statement above (ref: LMH-MD-010, 9-19 do nbt change the requirements for radiological sources, contamination control or shielding in any substantive manner uso pofregured per

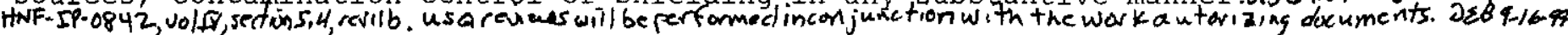

15. Distribution (include name, MSIN, and no. of copies)

see Attached Distribution sheet 


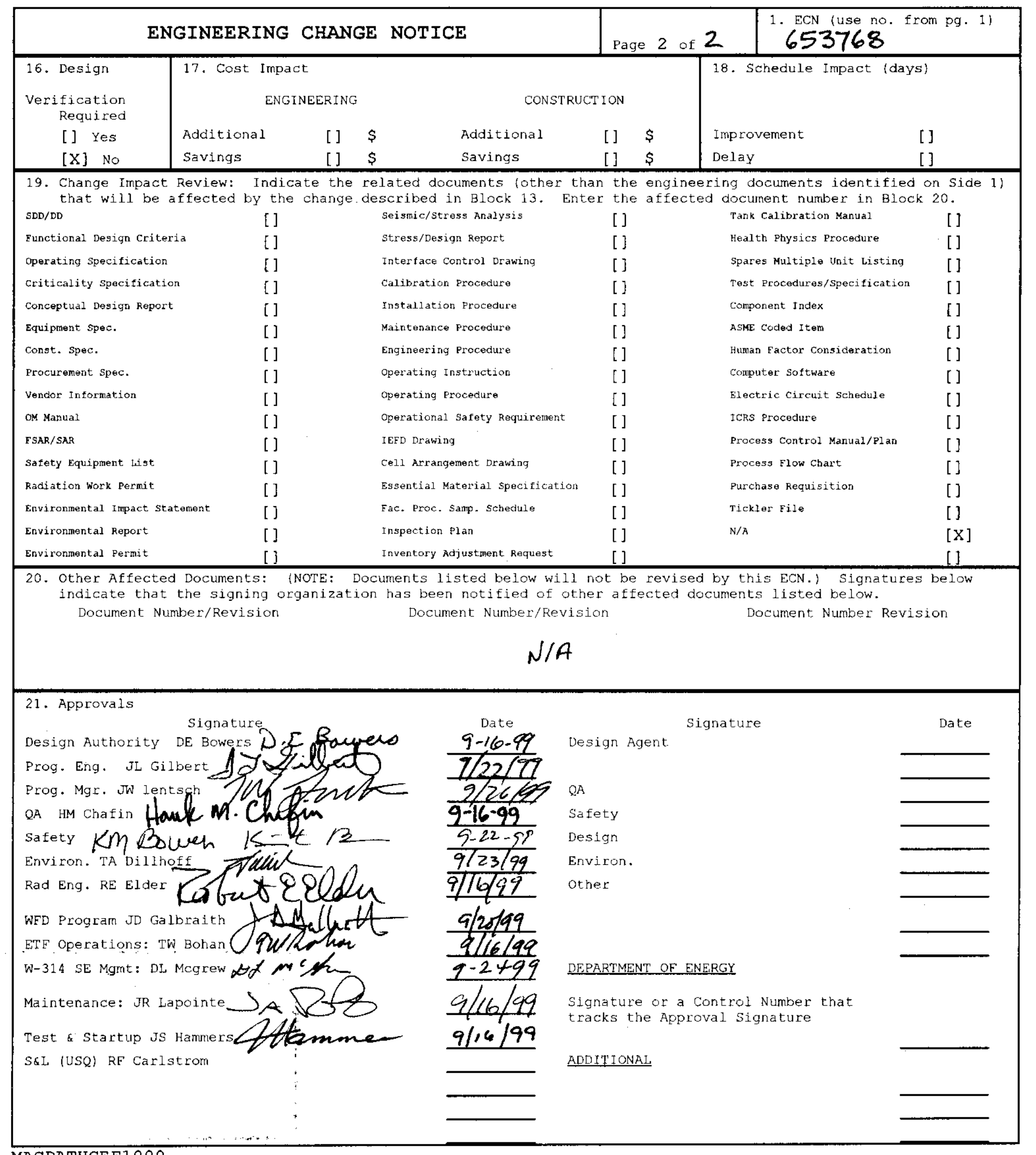




\section{Project Design Concept for Transfer Piping for Project $W-314$, Tank Farm Restoration \& Safe Operations}

\section{D.L. McGrew}

Numatec Hanford Corporation, Richland. WA 99352

U.S. Department of Energy Contract DE-AC06-96RL13200

EDT/ECN: 653768

Org Code: $8 \mathrm{C} 620$

B\&R Code: EW3130010
UC: 510

Charge Code: N311B

Total Pages: 24

25 PF 9-28-99

Key Words: $\boldsymbol{W}$-314, Design Concept. Transfer Piping, Tank Farm, Restoration and Safe Operation

Abstract: This Project Design Concept represents operational requirements for design of transfer piping system for Phase I of Project W-314, Tank Farm Restoration and Safe Operation Upgrades.

TRADEMARK DISCLAIMER, Reference herein to any specific commercial product, process, or service by trade name. trademark, manufacturer, or otherwise, does not necessarily constitute or imply its endorsement, recommendation, or favoring by the United States Government or any agency thereof or its contractors or subcontractors.

Printed in the United States of America. To obtain copies of this document, contact: Document Control Services, P.0. Box 950, Mailstop H6-08, Richland WA 99352. Phone (509) 372-2420: Fax (509) 376-4989.
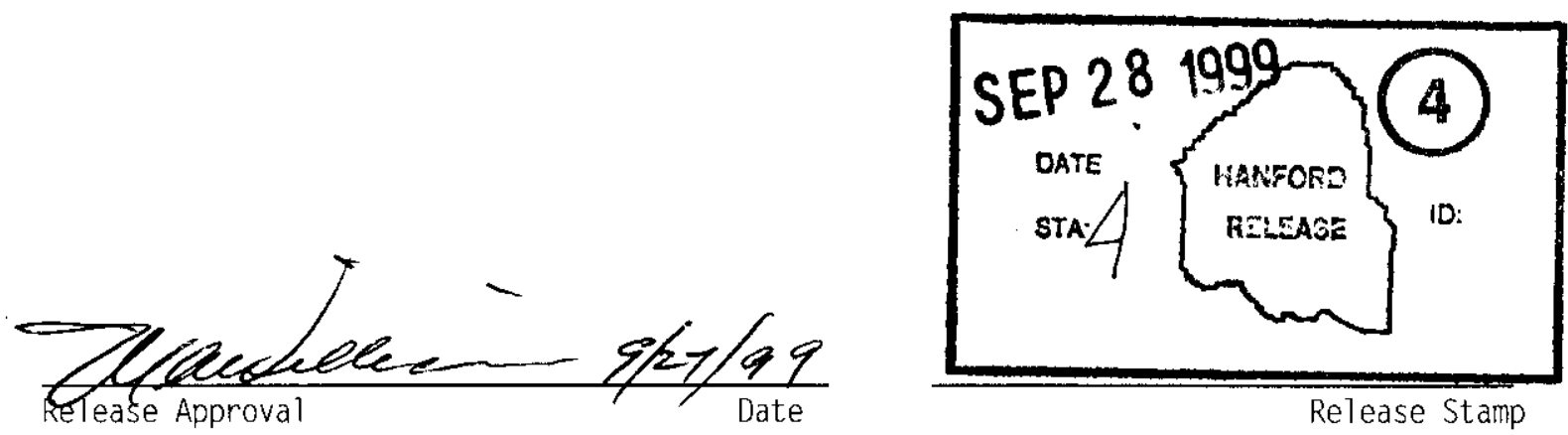

Release Stamp

\section{Approved for Public Release}




\section{RECORD OF REVISION}

(1) Document Number
HNF-SD-W314-TI-00
7

(2) Title

Project Design Concept - Transfer Piping for Project $W-314$

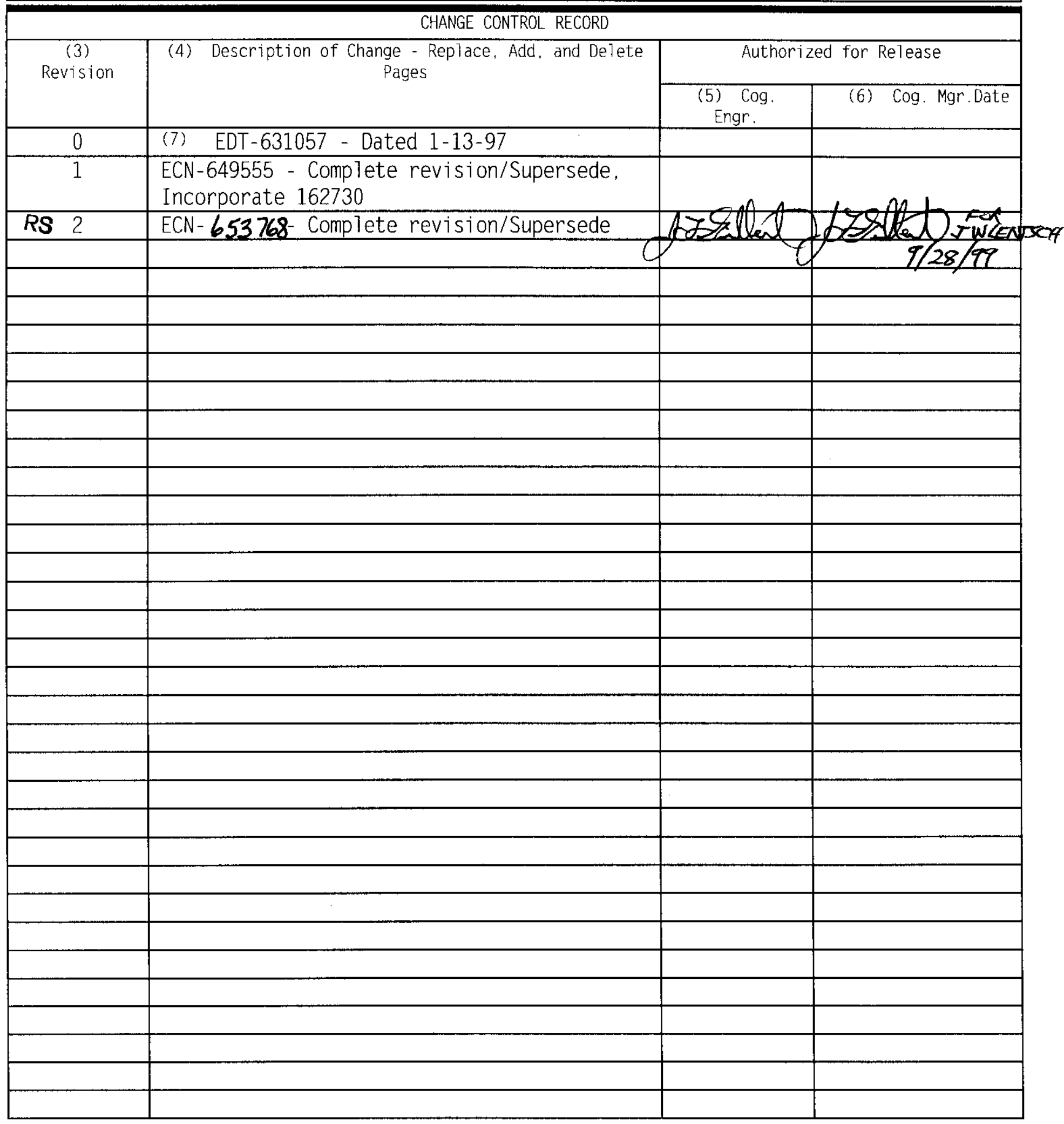




\section{Project Design Concept}

\section{Transfer Piping}

Project W-314

Tank Farm Restoration and Safe Operations

Prepared by Fluor Daniel Northwest, Inc. for Lockheed Martin Hanford Corporation

September 1999

Prepared by:

Concurrence:

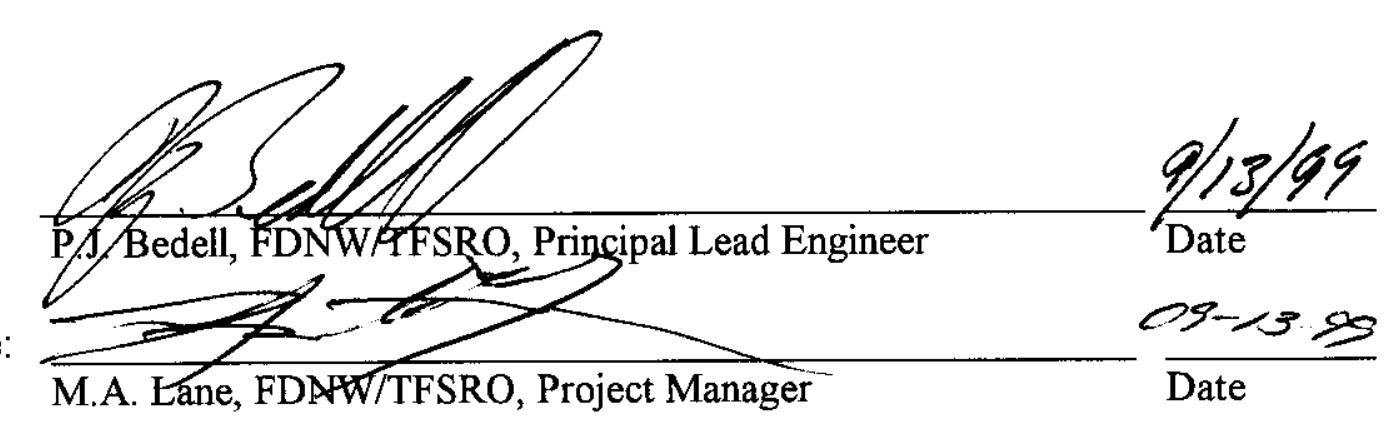

Approval:

Approval:

D.L. McGrew, NHC, Systems Engineering

Approval:

J.W. Lentsch, LMHC, Project Manager

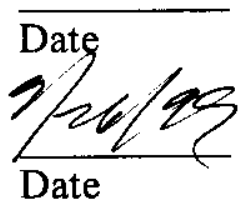

Approval:

D.C. Bawers

D.E. Bowers, LMHC, Design Authority

$\frac{9-16-99}{\text { Date }}$

Approval:

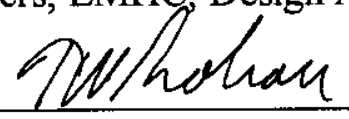

T.W. Bohan, LMHC, Project W-314 Retrieval Operations

$9 / 16 / 99$

Date

Approval:

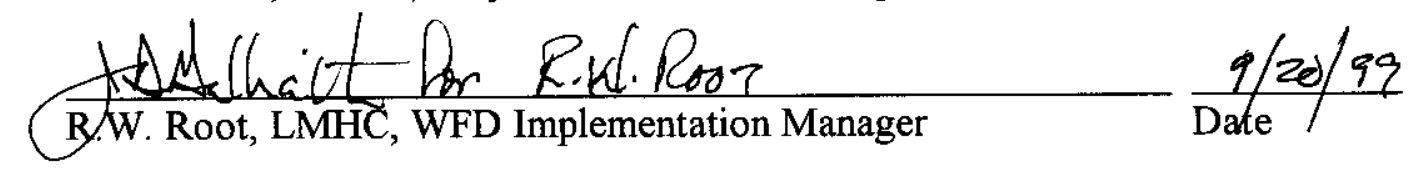




\section{CONTENTS}

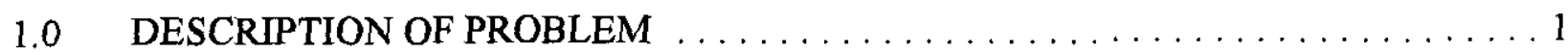

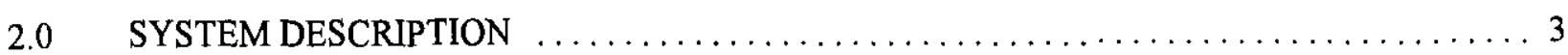

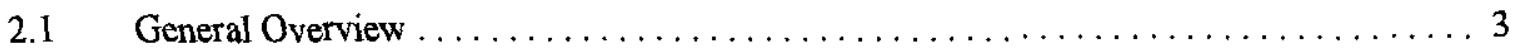

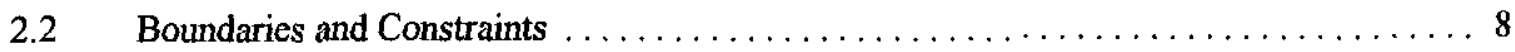

2.3 Performance Requirements. . . . . . . . . . . . . . . . . . . . . . 11

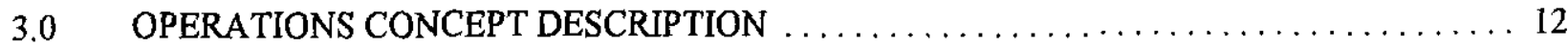

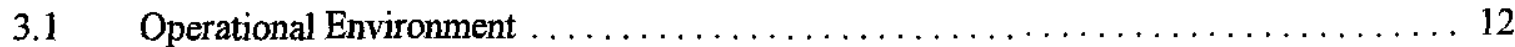

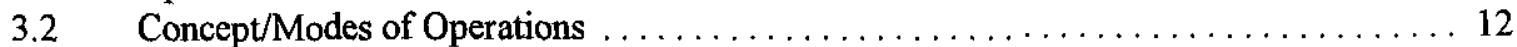

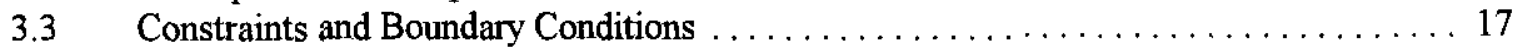

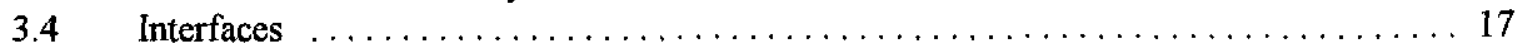

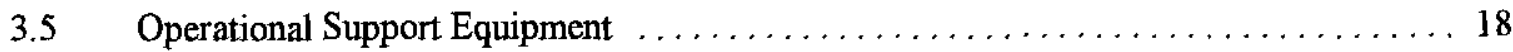

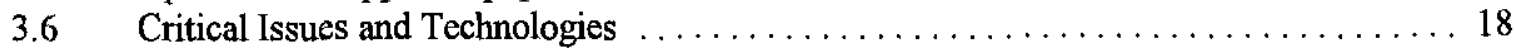

$4.0 \quad$ SUPPORT CONCEPT DESCRIPTION $\ldots \ldots \ldots \ldots \ldots \ldots \ldots \ldots \ldots \ldots$

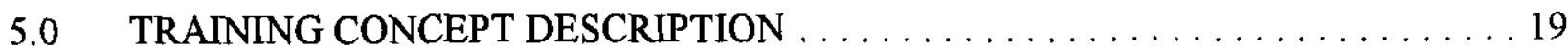

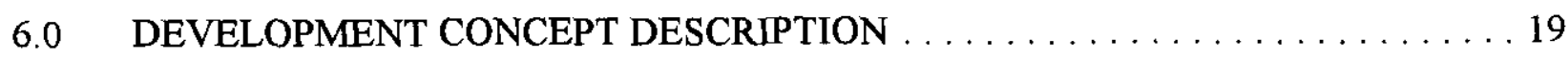

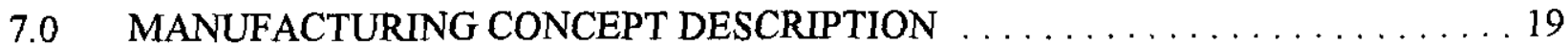

8.0 VERIFICATION CONCEPT DESCRIPTION $\ldots \ldots \ldots \ldots \ldots \ldots \ldots \ldots$

9.0 INSTALLATION AND START-UP DESCRIPTION $\ldots \ldots \ldots \ldots \ldots \ldots \ldots \ldots$

10.0 SYSTEM DECONTAMINATION AND DECOMMISSIONING (D\&D) . . . . . 20 


\section{LIST OF FIGURES}

Figure 1-1. Project W-314 Transfer System Mission. . . . . . . . . . . . . . 2

Figure 2-1. 200-East Area Waste Transfer System. .................... 6

Figure 2-2. Transfer System Conceptual Architecture. $\ldots \ldots \ldots \ldots \ldots \ldots \ldots \ldots$

Figure 3-1. Transfer Pipe Concept. . . . . . . . . . . . . . . . . . . 13

Figure 3-2. Cathodic Protection System Concept. . . . . . . . . . . . . . . . 14

Figure 3-3. Jumper/Valve Manifold Concept. ....................... 14

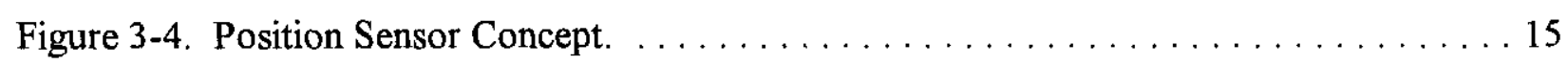

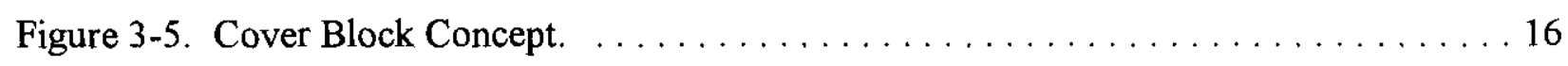


HNF-SD-W314-TI-007

Revision 2

\section{PROJECT DESIGN CONCEPT TRANSFER PIPING}

\subsection{DESCRIPTION OF PROBLEM}

Tank Farm Restoration and Safe Operation (TFRSO), Project W-314 was established to provide upgrades that would improve the reliability and extend the system life of portions of the waste transfer, electrical, ventilation, and instrumentation and control systems for the Hanford Site Tank Farms. An assessment of the tank farm system was conducted and the results are documented in system assessment reports. Based on the deficiencies identified in the tank farm system

I assessment reports, and additional requirements analysis performed in support of the Fank Waste

1 Remrediation System (TWS) River Protection Project (RPP), an approved scope for the TFRSO effort was developed and documented in the Upgrade Scope Summary Report (USSR), WHC-SD-W314-RPT-003, Rev. 3. The USSR establishes the need for the upgrades and identifies the specific equipment to be addressed by this project.

This Project Design Concept (PDC) is in support of the Phase 1 upgrades and provides an overall description of the operations concept for the W-314 Transfer Piping System. Actual specifications, test requirements, and procedures are not included in this PDC. The PDC is a "living" document, that is, it will be updated throughout the design development process to provide a progressively more detailed description of the W-314 Transfer Piping System design. The Phase 1 upgrades to the waste transfer system shall support the following operations as identified in Figure 1-1.

- Tank Farm Safe Storage Transfer Operations

Tank farm operations include current evaporator feed and delivery, cross-site transfers, and miscellaneous Double-Shell Tank transfers in support of waste consolidation. Tank Farm Safe Storage Transfer Operations include tank to tank waste consolidation transfers, evaporator staging/recycle/slurry transfers, catch tank to DST transfers, DCRT to DST transfers, and transfers into DSTs from external waste generators.

\section{- Phase 1 Low-Activity Waste (LAW) Immobilization}

Phase $1 \mathrm{LAW}$ immobilization is the vitrification of waste by a private contractor. The primary feed for the Phase 1 LAW immobilization is the supernate contained in the 24l-AN Tank Farm. This will be transferred to the 241-AP Tank Farm through a combination of the new waste transfer system and existing in-farm system. that bypasses the existing Houble-Shell Tank transfer system. 
Figure 1-1. Project W-314 Transfer System Mission.

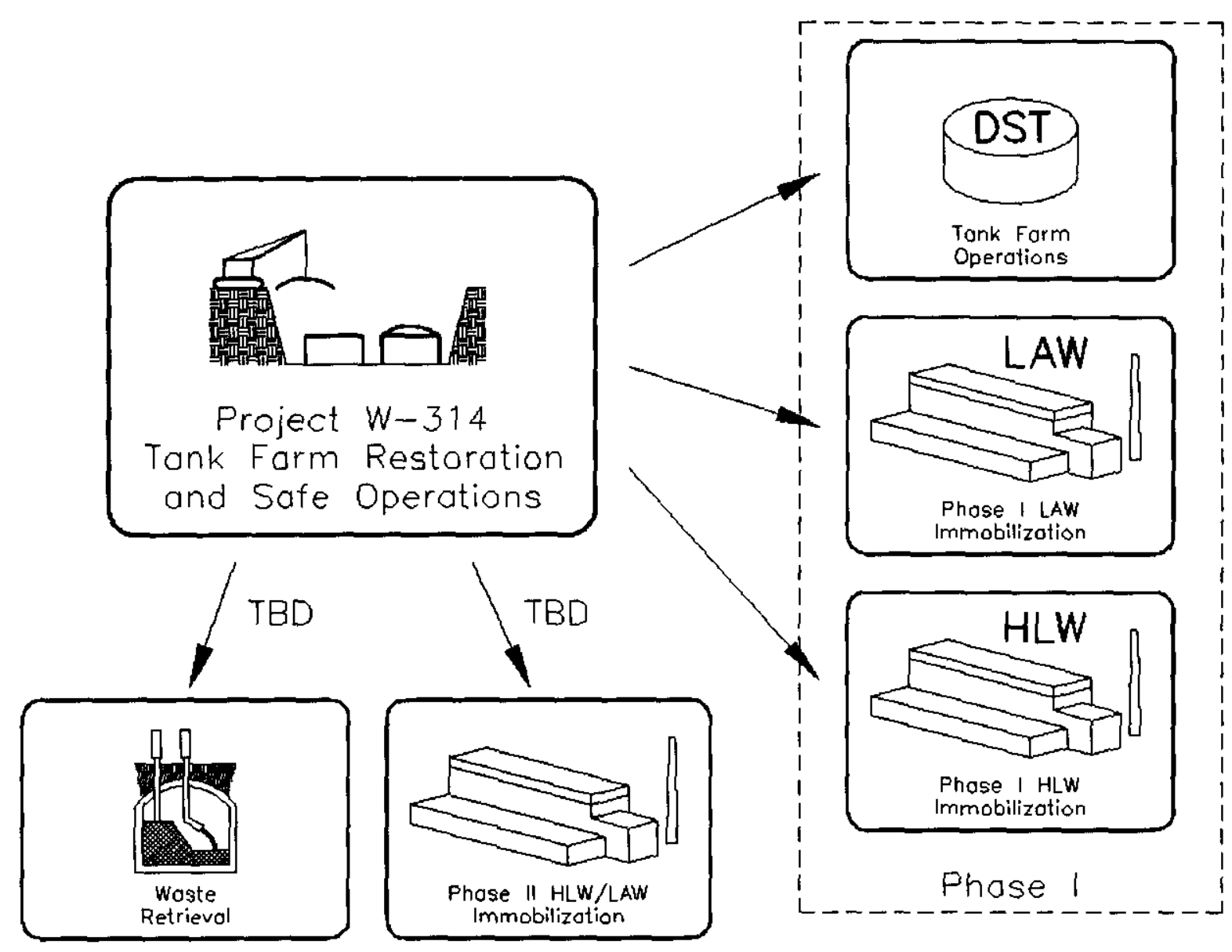

- $\quad$ Phase 1 High-Level Waste (HLW) Immobilization

Phase $1 \mathrm{HLW}$ immobilization is the vitrification of waste by a private contractor. The feed for the Phase 1 HLW immobilization will be slurry waste contained in the 241-AY and 241-AZ Tank Farms. This waste will be transferred directly to the HLW private contractor through new waste transfer lines .

The upgrades to the waste transfer system shall also support future DST Waste Retrieval and Phase 2 HLW/LAW immobilization. The requirements for the future missions are to be determined.

The Project W-314 Phase 1 upgrades including the new 200E Waste Transfer System (WTS) will allow a remedy to the following problems:

The existing transfer lines do not support to the extent desired the privatization feed transfer due to the systems reliability, operability, and flexibility issues.

The existing SN-200/213, -215, -216, SL-502, and -504 transfer lines are questionable for operation

throughout the life of the TWRS RPP mission. 
The existing jumper arrangements in the valve pits do not support the quick setup times required for the privatization feed requirements. The existing system requires pit entries to change transfer routes causing increased pit entries and exposure to personnel.

\subsection{SYSTEM DESCRIPTION}

\subsection{General Overview}

The transfer piping system addressed by this PDC is part of the Hanford DST waste transfer system. A schematic of the 200 East Area WTS is shown in Figure 2-1. The areas affected by this PDC are shown in bold.

The transfer piping system provided by Project W-314 consists of the following components as identified in Figure 2-2.

- Transfer Pipe, Item (1) - Pipe-in-pipe design with a 3-in nominal pipe size (NPS) primary pipe (inner pipe) and 6-in NPS encasement pipe (outer pipe). The encasement pipe for the new 200E Waste Transfer lines and cross-site extension shall be epoxy coated, foam insulated and jacketed with a fiberglass-reinforced polyester resin (FRP) jacket. (except the new transfer tines between the 241-AY-01A and-02A and 241-AZ-01A and-02A Central Pump Pits).

- Encasement Leak Detector, Item (2) (10) (13) - The cross-site extension piping shall use continuous leak detection system (13) with pull ports provided in the encasement pipe. The cross-site slurry line shall also use pressure buildup detection systems (10) in the encasement. All other transfer piping shall use a low-point leak detection system (2).

- Cathodic Protection, Item (3) - fmpressedeurrent system. Fhis is onty required for nonjacketed pipe. The new transfer piping system around the pump/valve pits are required to be connected with the existing eathodically protected pipe.

- $\quad$ Process Pit Jumper/Valve Manifolds, Item (4)

- Position Sensors, Item (5)

- Cover Blocks, Item (6) - new cover blocks for 241-AN-A and -B and 241-AW-A and -B Valve Pits, and the new 241-AZ Valve Pit and the new 241-AN-04D, Slurry Receiver Pit.

- $\quad$ Process Pits, Item (7)

- $\quad$ Pit Coatings or Liners, Item (8) - stainless steel liner for the new 241-AZ-VP Valve Pit. Complete coating of SPC for the new 241-AN=04D, Slurry Receiver Pit and new eover blocks and repair of existing coatings on existing pits and cover blocks. 
- $\quad$ Pit Leak Detectors, Item (9)

- Encasement Pressure Transmitters, Item (10), shall remotely monitor the status of the rupture disk, Item (11), and shatt status for the cross-site slurry line encasement.

- Burst Disk Indicator, Item (12), to indicate a burst disk for the cross-site slurry line extension only.

The transfer lines and process pit jumper/valve manifolds shall be capable of supporting transfers in both directions.

Two (2) cross-site transfer line extensions which includes the transfer pipe with insulated and jacketed encasement and continuous leak detection system shall be provided. Transfer line SLL-3160 shall extend from a tie-in point near the 244-A Lift Station to the new process pit located at 241-AN-104 Tank. The cross-site slurry line (SLL-3160) encessement pressure shall be monitored to detect leak prior to bursting a rupture disk. The SNL-3150 transfer line shall extend from a tie-in point near the 244-A Lift Station to the 241-AN-01A Central Pump Pit.

Six (6) Eight (8) waste transfer lines with insulated and jacketed encasement and low-point leak detection shall be provided. The new transfer lines shall be between the following new and existing process pits:

1. The 241-AN-01A Central Pump Pit and the new 241-AZ Valve Pit (SN-630).

2. The 241-AZ-01A Central Pump Pit and the new 241-AZ Valve Pit (SN-632).

3. The 241-AY-02A Central Pump Pit and the new 241-AZ Valve Pit (SN-633).

4. The new 241-AZ Valve Pit and the 241-AP Valve Pit (SN-634).

5. The 241-AN-04A Central Pump Pit and the new 241-AP-04D (Project W-211) Pump Pit (SN-636).

6. The new 241-AZ Valve Pit and the Privatization Contractor (PC) interface point (SN-637)

7. The 241-AZ-01A and 241-AZ-02A Central Pump Pits(SN-631)

8. The 241-AY=01A and 241-AY=02A Central Pump Pits(SN-635)

New process pit jumper/valve manifolds, including valve position sensors and new cover blocks, shall be provided for the following existing process pits:

- 241-AN-A and -B Valve Pits.

- 241-AW-A and -B Valve Pits.

- 241-AP Valve Pit (partial jumper/valve manifold and valve position sensors only).

- 241-AN-01A Central Pump Pit (jumper/valve manifold and valve position sensors only). 
1 fwo (2) One (1) new process pit including jumper/valve manifolds, valve position sensors, cover blocks, stainless steel liners, and pit leak detection systems shall be provided. The new process pit shall be as follows:

- 241-AZ Valve Pit - this valve pit shall control transfer routings within the new 200E WTS lines.

I One (1) new process pit with an encased pipe, cover block(s), pit leak detection system, redundant eneasement pressure transmitters and encasement rupture disk shall be provided. The new process pit shall be as follows:

241-AN-04D, Slurry Receiver Pit - this pit shall provide isolation of the SLL-3160 cross-site transfer line for periodic pressure testing and encasement drainage. 
Figure 2-1. 200-East Area Waste Transfer System.

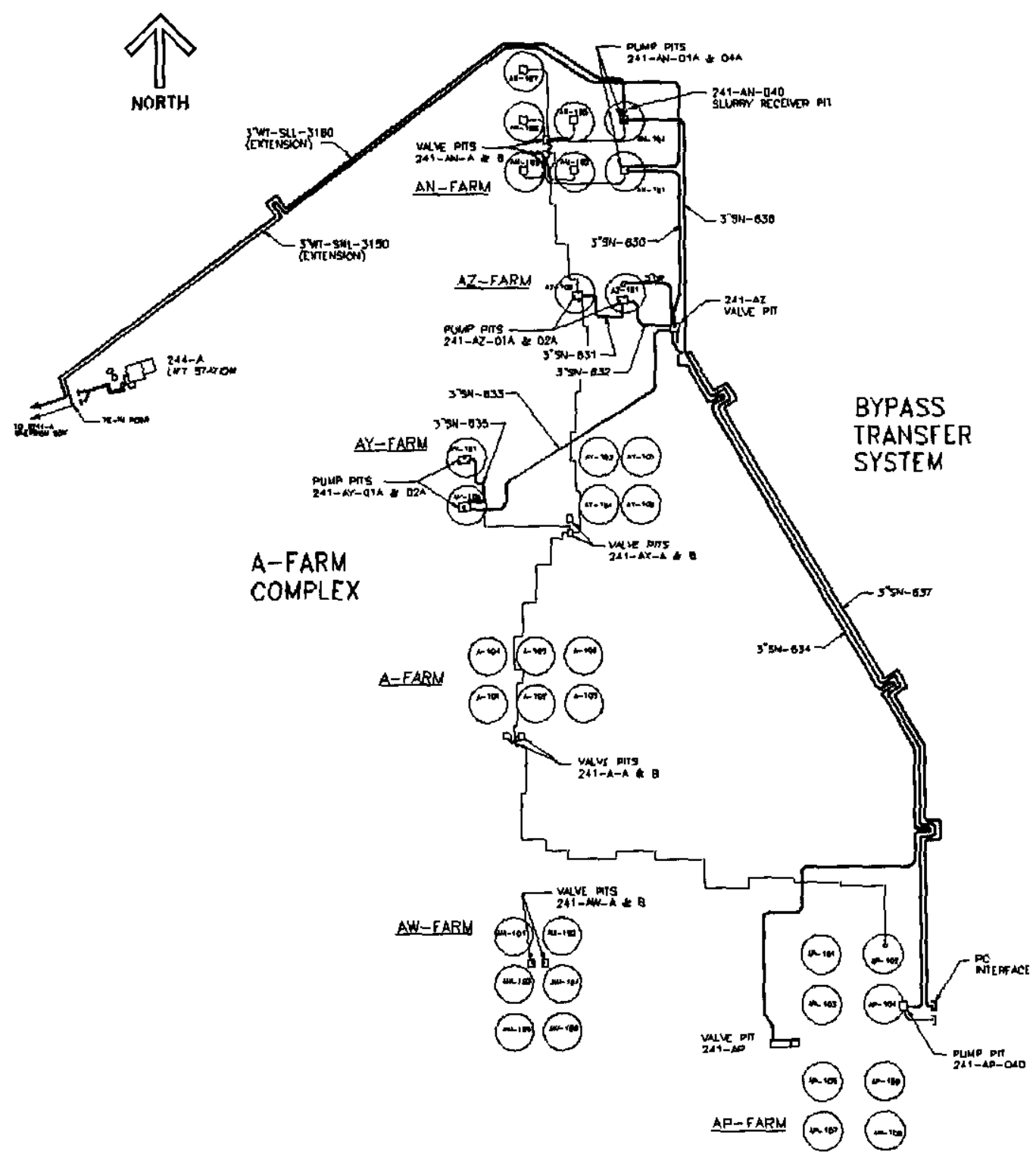


Figure 2-2. Transfer System Conceptual Architecture.

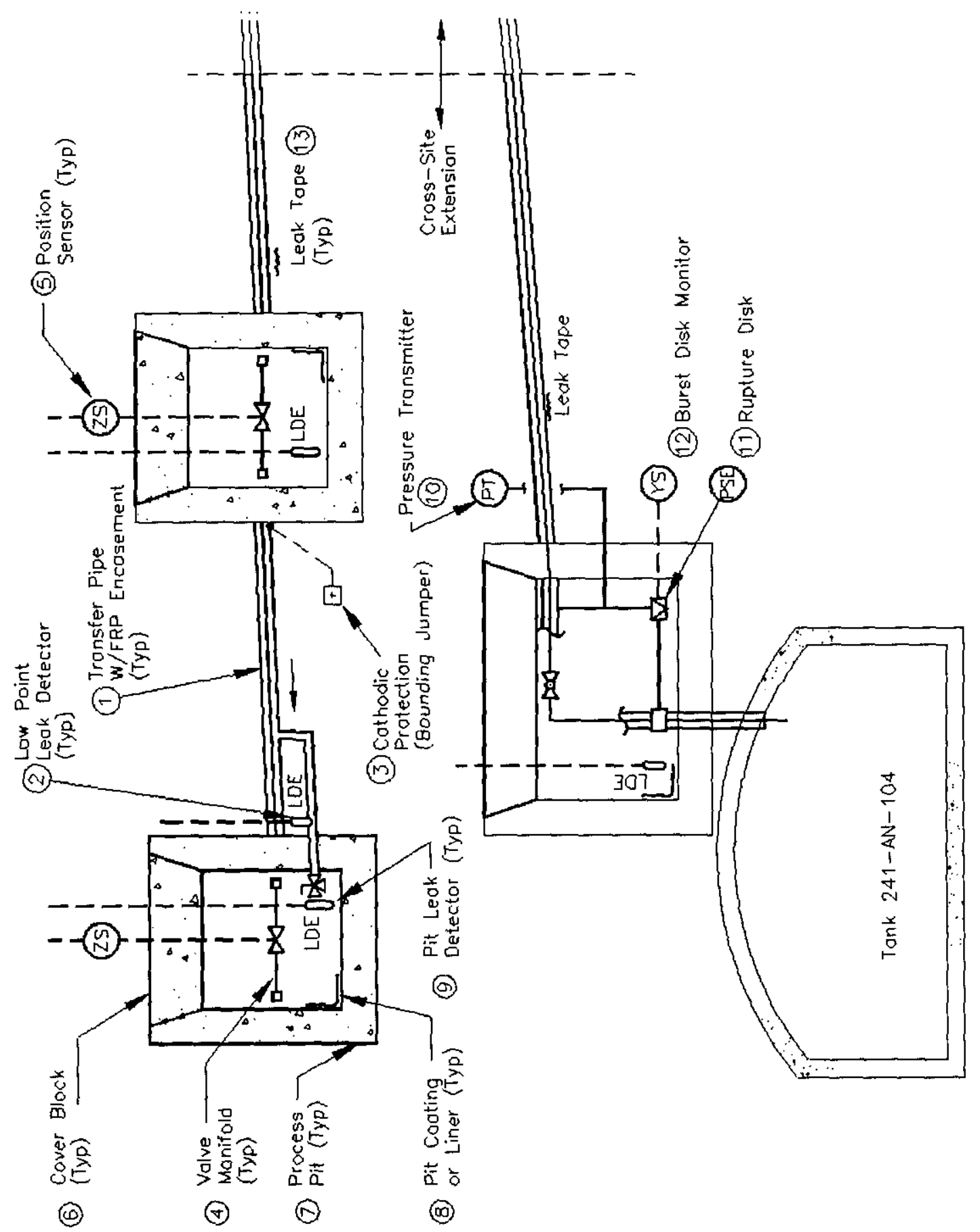


I Pit coatings repair and new pit leak detection systems shall be added to the following existing process pits:

- 241-AN-A and -B; 241-AW-A and -B; and 241-AP Valve Pits.

- 241-AN-01A and -04A; 241-AZ-01A and -02A; and 241-AY-01A and -02A Central Pump Pits.

I Pressure transmitters with high pressure alarms and rupture disk shall be provided on the encasement in 241AN=04D, Slurry Receiver Pit.

\subsection{Boundaries and Constraints}

The assessment of the tank farms documented in the USSR showed that specific, detailed tank farm enditems needing upgrade and/or replacement to support current operations and Phase I LAW/HLW immobilization. This leads to a transfer system heavily constrained by existing systems and current operating philosophies. These constraints are detailed below for the end-items and major components of the W-314 Transfer Piping System.

Transfer Piping

- The transfer piping shall be connected to the existing pits identified in Section 2.1. The elevations at the pits are fixed by the current nozzle arrangements.

- The new transfer piping shall be compatible with current installed designs to support privatization needs ( 3 " lines recommended).

- The 200E Waste Transfer lines shall have an epoxy coated, insulated, epoxied and fiberglass jacketed encasement piping to match the existing cross-site piping which provides exterior corrosion protection for the encasement piping to match the existing (except the transfer lines between 241-AY-01A and -02A and 241-AZ-01A and -02A Central Pump Pits).

- The primary pipe shall be stainless steel.

- The $200 \mathrm{E}$ cross-site extension piping shall be designed to the same code of record of the existing cross-site transfer lines and the remaining transfer lines shall be designed to the requirements specified.

Encasement Leak Detector

- All encasement leak detection signals, except cross-site extension line, shall be provided with local alarm indication and shall provide input to the Master Pump Shutdown (MPS) System.

- The high encasement pressure alarm system for the cross-site slurry line (SLL-3160) shall 


\section{provide a local alarm and shall provide an input to the MPS system.}

- Loss of power to the leak detection probes and a detected failure of the leak detection system shall provide an output signal to the local alarm and MPS.

- The encasement leak detection system for the cross-site transfer line extensions shall be a PermAlert AGW-Gold/RT continuous leak detection eable system and shall be monitored and shall input to the Master Pump Shutdown System and into the existing cross-site transfer control system.

- Hand held radio and cell phone wattage frequency shall not interfere with the encasement leak detection system components at a distance of $3.3-\mathrm{ft}$.

- Encasement leak detection system shall not be adversely affected by outside electromagnetic forces.

- Low point encasement and encasement pressure bulldup leak detector operation shall be remotely veriffed by the MPS System.

Cathodic Protection System (ifapplicatie)

- The eathodic protection new transfer piping system shall be compatible with the adjacent existing cathodic protection systems and buried structures.

- Existing cathodic protection system may require adjustments due to installation of the new insulated piping.

Process Pit Jumper/Valve Manifolds

- Valves shall be manually operated from above the cover blocks.

- The jumper/valve manifolds shall physically fit within the designated pits and connect to transfer lines at the pit wall nozzles.

- Valves shall lend themselves to future remote operation by motors installed above the cover blocks.

- Valves shall be maintenance free over a 12 year design life with up to 1000 cycles.

- Valve handles shall be uniquely identified, removable, and designed with positive indication of proper seating of the valve operator.

- The valve position indication system shall provide sufficient accuracy with respect to the actual valve position such that the selected flow path configuration is leak tight. 
and/or operators will be provided with mechanical stops. The valve extension handle will fail safe in an over torque situation.

- Valve operators shall be provided with a method to securely lock the valve in current position using a padlock commonly used by operations personnel.

Position Sensors

- The valve position sensors shall be located above the cover blocks. Manual indication on the valve shall be visible when the extension handle is removed.

- Indication of valve position must match the physical position of the valve at each position limit.

- Valve position system shall not be adversely affected by outside electromagnetic forces.

- Hand held radio and cell phone wattage frequency shall not interfere with the valve position sensor system components at a distance of 3.3-ft.

Cover Blocks

- The new pit cover blocks shall physically fit the designated pits.

The cover blocks stalt be easity rentovect using a +10 ton erane positionect off the tank tome. The new pit cover blocks (maximum weight of 17 tons) shall be capable of being removed using 110 ton wheeled Grove crane positioned off the tank dome. eover block is approximately 17 tons:

Process Pits

- A new pit shall be installed around a suitable riser on Tank 241-AN-104 for connection of the extension of transfer line SLL-3160. The pit shall drain to a low point drain equipped with leak detection. The drain shall return to Tank 241-AN-104.

Pit Coatings

- $\quad$ SPC shall be compatible with existing coating systems. Stainless steel liners for the new process pits 241-AZ Valve Pit.

Pit Leak Detectors

- $\quad$ All signals from the new pit leak detection systems shall be provided with local alarm indication and shall provide input to the Master Pump Shutdown System. 
- Loss of power to the leak detection probes and a detected failure of the leak detection system shall provide an output signal to the local alarm and MPS.

- Hand held radio and cell phone wattage frequency shall not interfere with the pit leak detection system components at a distance of $3.3-\mathrm{ft}$.

- $\quad$ Pit leak detection system shall not be adversely affected by outside electromagnetic forces.

\section{- Pit leak detection system shall be remotely verifed as operatonal by the MPS Sytems.}

\subsection{Performance Requirements}

The W-314 Transfer Piping System upgrades shall meet the following system level performance requirements with appropriate design margins:

a. Support the tank farm waste transfers as identified in the Tank Waste Remediation System Operation and Utilization Plan (TWRS SOUP), HNF-SD-WM-SP-012.

b. Support transfer of tank farm waste with the following waste properties:

$\begin{array}{lll}\text { Specific Gravity } & 1 \text { to } 1.5 & \\ \text { Temperature } & 10 \text { to } 93^{\circ} \mathrm{C}\left(50 \text { to } 200^{\circ} \mathrm{F}\right) & \\ \text { Design Pressure } & \text { Cross-site transfer line extension } & 1490 \mathrm{psi} \\ & \text { All other transfer piping } & 400 \mathrm{psi}\end{array}$

c. Maintain primary and secondary containment of transferred wastes throughout the 35-year design life of the W-314 Transfer Piping System.

d. Provide flow paths for selected active waste routings in the process pits. Active transfer routes are transfer lines that will be used in support of future operations and DST retrieval.

e. Provide selected continuous verification of waste transfer routing and provide a shutdown signal to the new MPS system upon the detection of an inappropriate valve position.

f. Provide a minimum slope of the transfer lines of $0.25 \%$ for drainage and a maximum slope of $10 \%$.

Detailed performance requirements for the W-314 Transfer Piping System elements shall be documented in the Project Development Specifications (PDSs) 
HNF-SD-W314-TI-007

Revision 2

\subsection{OPERATIONS CONCEPT DESCRIPTION}

\subsection{Operational Environment}

The W-3 14 Transfer Piping System exists in the external environment at Hanford, with some buried components and some components in radiation environments. Specific environmental requirements for the end-items and major components shall be documented in the PDSs.

\subsection{Concept/Modes of Operations}

\subsubsection{Transfer Pipe}

The transfer pipe is used to move liquid waste from one double-shell tank to another. The transfer piping shall be self-draining and capable of moving waste in either direction. Shielding from radiation emitted by the waste being transferred shall be provided by burying and/or berming the transfer piping. In addition, the transfer pipe shall be buried below the freeze level or be provided with a method of freeze protection.

The transfer pipe shall use a dual pipe (pipe-in-pipe) design as secondary containment (see Figure 3-1). The primary pipe is surrounded with a second pipe (the encasement). Each encasement shall be equipped with an encasement pressure riser at the high-end so that the encasement can be pressure tested to verify its integrity. In addition, each encasement shall be equipped with a leak detection system that alarms if a leak in the primary pipe occurs. The encasement pipe for the new 200E WTS lines and cross-site extension shall be epoxy coated, foam insulated, and jacketed with an FRP jacket. Figure 3-1 shows a section through the pipein-pipe system for the eoted, instuted and jacketed and nonjacketed encasement. One method used to support and center the primary pipe in the secondary containment pipe also is shown. The eneasements for the cross-site extension lines shall be protected against overpressure by rupture disks. The rupture disk for the eross-site slurry line (SLL-3160) shall be equipped with burst disk indicator. The slurry line (SLL-3160) shall drain to Tank AN104. The eross-site supernatant transfer line (SNL-3150) shall drain/vent to Waste Tank 101 via pump pit AN01A.

\subsubsection{Encasement Leak Detector}

The encasement leak detection system shall continuously detect the presence of liquid in the space between the pipes. However, the encasement shall be capable of being sealed off for pressure testing. The cross-site extension piping SNL-3150 and SLL-3160 shall use continuous leak detection system with pull ports provided in the encasement pipe. The cross-site surry line ( $\mathbf{L L}-3160$ ), in addition to the continuous leak detectors, shall use an eneasement pressure monitoring system that will detect build-up of gas pressure in the encasement caused by leak in the primary line. All other transfer piping shall use a low-point leak detection system.

The pressure monitoring system shal provide encasement pressure indication via the MPS system during preoperational encasement line testing. 
HNF-SD-W314-TI-007

Revision 2

I The encasement leak detection system shall be capable of failsafe operation and shall monitor the leak detector wiring

Figure 3-1. Transfer Pipe Concept.
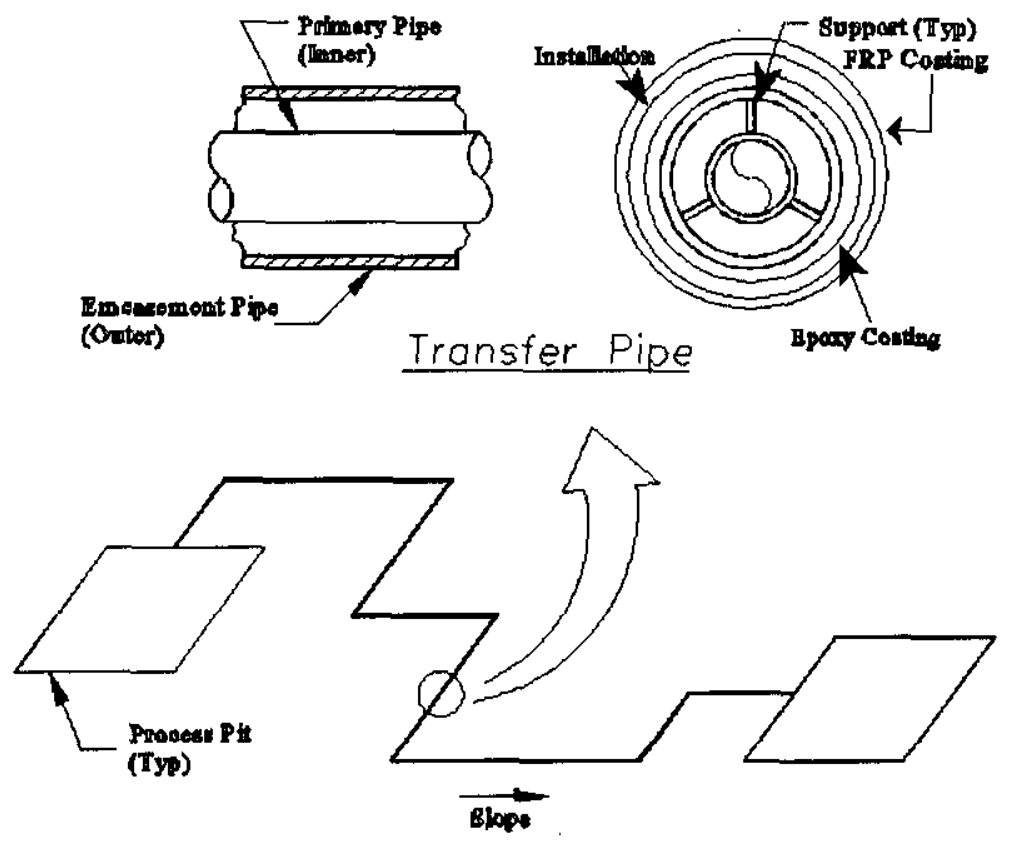

1 The cross-site extension encasement leak detector shall be installed in a pipeline the bottom of the encasement and the encasement shall be sealed to maintain a dry environment jacket seated with chy nitrogen. When moisture is detected by the leak detector, the continuous leak detector control unit shall shutdown the cross-site transfer and identify the location of the leak as a distance from the control unit.

An output from a low point encasement leak detection system or the cross-site slurry line encasement pressure alarm system to the Master Pump Shutdown (MPS) System shall activate a local alarm and send a i signal to the Master Pump Shutdown (MPS) System. The local alarm shall be located near the leak detector inside the tank farm fence. The intention of the alarm is to notify personnel located in the tank farm where the leak has occurred. The local alarm shall be a white light, visible in the tank farm. The alarm light shall flash until the alarm condition has cleared and acknowledged by an operator at the leak detection panel, at the MPS Human-Machine Interface (HMI) in the Tank Farm Instrument Building or at the Operating Center responsible for the Tank Farm in the state of alarm. The MPS system and TMACS shall also have alarm operation procedures.

\subsubsection{Eathodic Corrosion Protection System}

For the nonjacketed encased piping, the steel of the buried encasement pipe is subject to external galvanic 
corrosion resulting from bacterial and chemical activity in the soil. The piping system is protected from such corrosion by an epoxy coating, insulation, FRP jacket, and bonding with the existing cathodically protected

I pipe. The objective of the cathodic protection system is to provide the transfer piping system with a method that will minimize failures and will help ensure safe and environmentally sound waste management operating conditions.

The concept of cathodic protection is simple with the understanding that corrosion is basically an electrochemical reaction. Essentially, cathodic protection forces the chemical reaction of corrosion to reverse by forcing electrons to flow in the opposite direction. As shown in Figure 3-2, electrons are forced onto the pipe by the source of direct current,

Figure 3-2. Cathodic Protection System Concept. the rectifier. Current is forced to flow from the anode, through the soil and is picked up by the pipe surface. Any corroding areas of the pipe will experience a reversing reaction and the pipe becomes protected from corrosion.

I The eathodic protection system shall be tied into the existing site cathodic protection system. Existing active piping in the proximity of the protected pipe shall be electrically bonded, by a jumper wire, into the cathodic protection circuit to avoid accelerated corrosion by stray currents.

\subsubsection{Process Pit Jumper/Valve Manifolds}

Transfer lines enter pits and terminate at nozzles. The nozzles are connected by the jumper/valve manifold.

The jumper/valve manifold concept is to provide all necessary waste routing configurations within a pit (see Figure 3-3). The valve manifold shall allow any active transfer route to be selected and eliminate the need to reconfigure jumper arrangements. Jumper/valve manifolds shall be connected only to the active 3 -in supernate (SN) piping system within the pits.

Connections to the 2 -in slurry (SL) piping systems shall be excluded with a few specific exceptions, as identified in the PDS.

Separate manifolds shall be utilized in pits where connections to both the SN and SL piping is required, however, the capability to cross-tie these manifolds shall be provided. Each 3-in manifold shall have a valved nozzle to

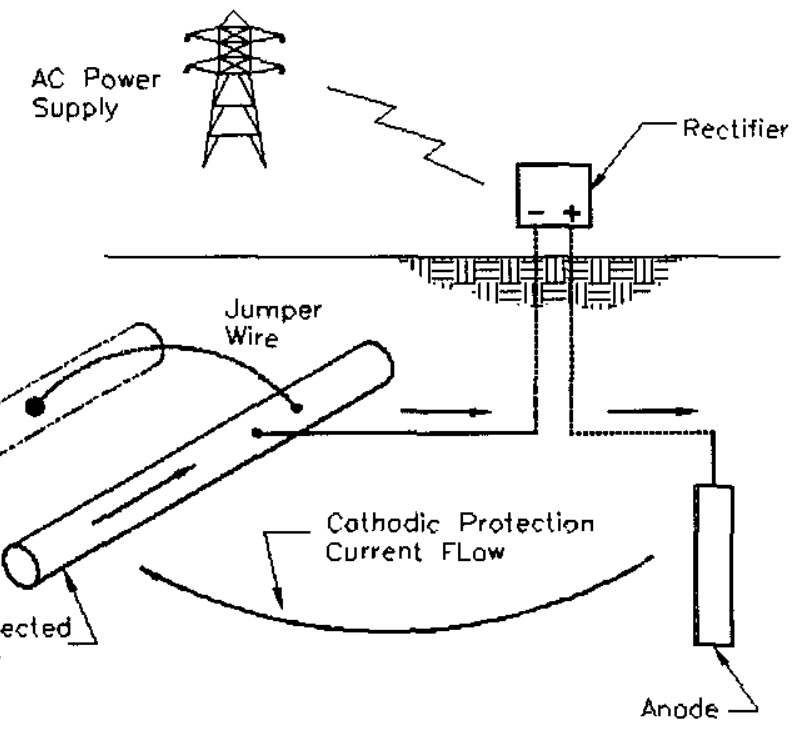

Figure 3-3. Valve Manifold Concept.

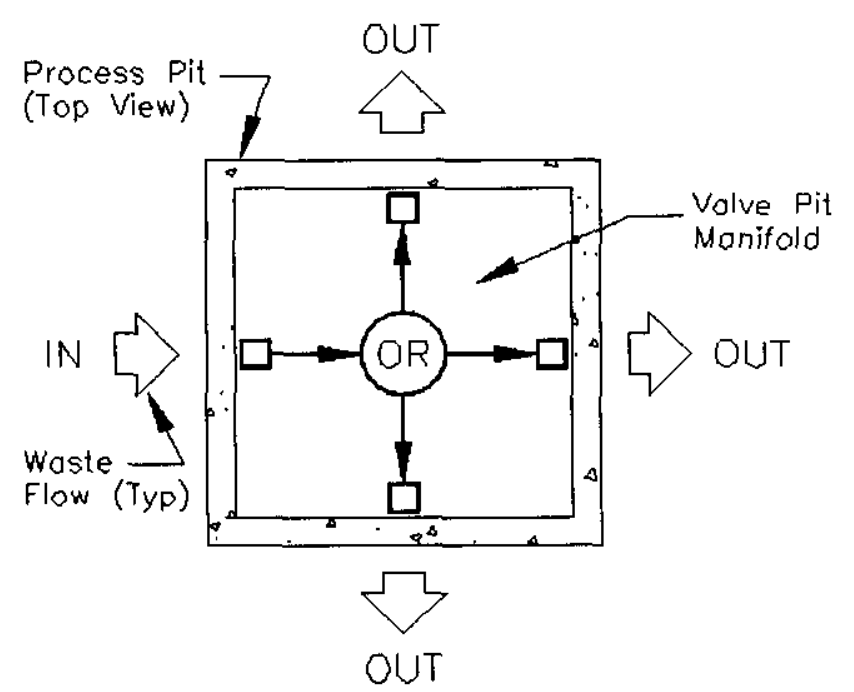


facilitate interface with the existing transfer piping system via flexible jumper provided by others. All unused nozzles shall be sealed off.

Transfer routes shall be selected and configured by turning the manifold valves with handles that extend through the process pit cover. However, the design of the valve handle extension shall allow for the addition of motor-operated actuators. Block valves shall be provided to ensure two valve isolation from transfer lines/flush piping that is not in the desired flow path. It is acceptable to have the second block valve one pit away. The manifold shall be designed so that waste and flush water will drain out of the manifold and avoid the trapping of liquids. In addition, stainless steel valves and piping shall be used to facilitate decontamination. The manifold is supported by structural members that rest (unanchored) on the pit floor.

I A crane crew is required to install the valve manifold in the process pits, and a crane- remote-operated wrench is used to connect the manifold to the pit nozzles.

\subsubsection{Position Sensors}

The position sensors provide continuous verification of the valve positions in the process pit jumper/valve manifolds (excludes encasement drain valves). The system shall use position sensors located on the valve operator located above the cover blocks (see Figure 3-4). Protection from any inadvertent physical abuse shall be provided. In addition, the position sensor shall be designed to facilitate quick mechanical/electrical disconnect for ease of cover block removal and replacement. The position sensors shall send a signal to the MPS system if a change in the valve position is detected during a transfer.

\subsubsection{Cover Blocks}

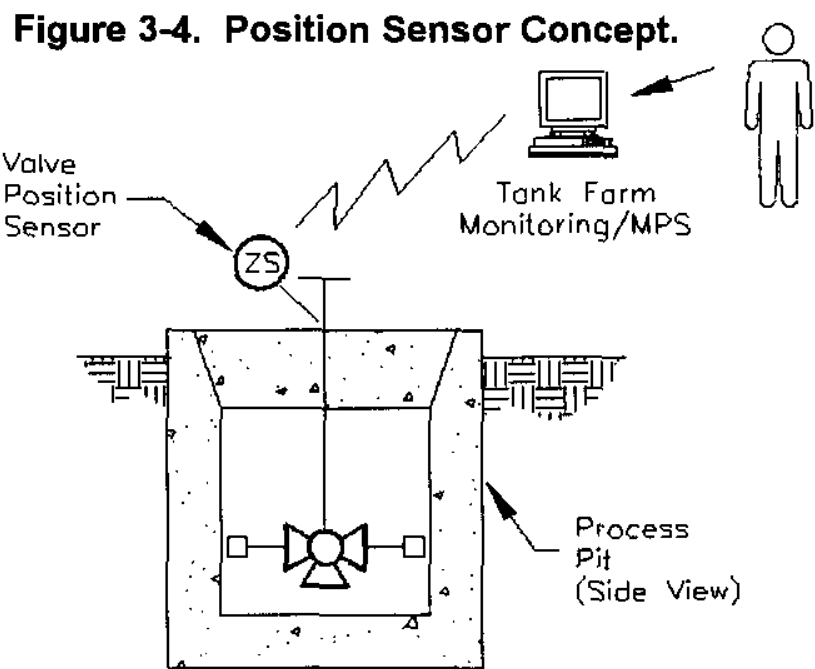

The pit cover blocks form part of the secondary confinement barrier of the pit and provide radiation shielding for operations personnel (see Figure 3-5). New cover blocks shall be constructed of structurally reinforced concrete sized and shaped to reduce the radiation exposure to operating personnel. The ends of the cover blocks shall be stepped to preclude radiation streaming. In addition, the new cover blocks shall be sealed to protect the pit from ingress of foreign matter. 
The pit cover blocks shall be equipped with penetrations to facilitate valve operation, maintenance of leak detectors, pit washdown, gas sampling ports, and installation of support equipment (e.g., cameras, etc.). These penetrations shall be sealed to protect the pit from ingress of foreign matter.

The cover block design shall include lifting mechanism, an alignment mechanism, and be sectional to facilitate easy installation and removal by a standard tank farm crane (maximum 110 ton) located off the tank dome.

The top of the new cover blocks shall be clear of tripping hazards, to the greatest extent practical, and shall be painted to show the valve manifold layout within the pit and the cover block weight. In addition, the new cover blocks shall be treated with a special protective coating material as identified in Section 3.2.8.

\subsubsection{Process Pits}

Process pits are used to contain the jumper/valve manifolds to change waste transfer routes. Process pits also provide containment for leaks in transfer lines (which drain back to the pits via pipe-in-pipe encasement) and leaks in jumpers and connections.

The process pits shall be constructed of structurally reinforced concrete The process pits shall be equipped with watt nozztes if jumpertvatve manifotds sleeves for wall nozzles are to be instatted in the pit. If the piping is hard piped in the process pit, any valves used shall be designed such that the seats and seals can be replaced I remotely. The new 241-AZ Valve Pit shall be lined with stainless steel on the bottom and part of the way up the sides. The new 241-AN-04D, Slurry Receiver Pit shall not be stainless steel lined but will rely on special protective coating-SPC for protection. In addition, they shall be equipped with drains that drain to a nearby DST. To provide for future expansion of the transfer system, spare nozzles sleeves shall be installed in the $\mathrm{AZ}$ process pit. that will utilize valve manifolds. The spare nozztes shatl be stubbet off outside the pit so new lines can be connected without breaking into the sides of the pit:

\subsubsection{Pit Coatings and/or Liners}

The pit coatings and liners shall protect the interior and exposed surfaces of the pits and cover blocks by establishing a physical barrier between the structural secondary containment and any waste present in the pit due to leaks, spills, or intrusion. The coating and liner material shall have low permeability, and shall be chemically and radiologically compatible with the tank waste, including high corrosion resistance and be I readily decontaminated. 
HNF-SD-W314-TI-007

Revision 2

\subsubsection{Pit Leak Detectors}

The pit leak detection system shall be a dedicated, alarm-connected sensor that detects the presence of liquid 1 in the pits. Pit leak detection sensors shall be located no higher than +2 -in above the floor in the lowest part of the pit or in a sump in the pit. The pit leak detector shall be capable of being tested in place. In addition, the pit leak detector shall be capable of being removed without requiring pit entry. The pit leak detector shall also be capable of failsafe operation and shall monitor the leak detector wiring.

An output from a pit leak detection system to the MPS System shall also activate a local alarm. The local alarm shall be located near the leak detector inside the tank farm fence. The intention of the alarm is to notify personnel located in the tank farm where the leak has occurred. The local alarm shall be a flashing light and horn, visible and audible in the tank farm. The alarm light shall flash until the alarm condition is cleared and acknowledged by an operator locally at the leak detector panel, at the MPS HMI in the Tank Farm Instrument Building or the Operating Center responsible for the Tank Farm in the state of alarm. The MPS system and TMACS shall also have alarm operation procedures.

\subsection{Constraints and Boundary Conditions}

The main operational constraints and boundary conditions are with the existing pit designs. The process pit jumper/valve manifolds shall use the PUREX type connector heads for remote connections. In addition, the valves shall be manually operated from above the cover blocks and shall be capable of being converted to motor-operated actuation.

\subsection{Interfaces}

The W-314 Transfer Piping System interfaces are described below for the system end-items and major components (see Figure 2-2):

- Transfer Pipe, Item (1) - connection to the existing transfer system at the respective process pits; connection to the existing cross-site transfer system at the tie-in points; and connection to existing DST 241-AN-104 for the SLL-3160 transfer line.

Encasement Leak Detector, Item (2) - connection to the Fank Farm Monitoring MPS System and Site Power. In addition, the cross-site extension piping leak detection cable will interface with the existing cross-site leak detection system. Additionally, modifications shall be made to the cross-site transfer control system (PLC and HMI software) and the 242-A DCS system to reflect the changes made because of the new 200E WTS configuration.

- Cathodic Protection, Item (3) - electrically bonded to existing unprotected structures and connection to the Site Power.

- Process Pit Jumper/Valve Manifolds, Item (4) - connection to the existing pit nozzles.

- Position Sensors, Item (5) - connection to the Tank Farm Monitoring/MPS System and Site 
Power.

- Cover Blocks, Item (6) - connection to the existing process pits.

- $\quad$ Process Pits, Item (7) - connection as required to existing DSTs for new process pit drains.

- $\quad$ Pit Coatings, Item (8) - connection to the existing valve pits.

- $\quad$ Pit Leak Detectors, Item (9) - connection to the Tank Farm Monitoring/MPS System and Site Power.

- Encasement Pressure Alarm System, Item (10) - connection to the MPS System and Site Power.

- Remotely monitored rupture disk, Item (11), connected to for the cross-site slurry line encasement.

- Burst Disk Indicator, Item (12) - connection to the MPS System and Site Power,

Detailed interfaces for the W-314 Transfer Piping System elements shall be documented in the Project W314, Project Interface Control Document (PICD) (HNF-SD-W314-PICD-001).

\subsection{Operational Support Equipment}

The W-314 Transfer Piping System shall use existing operational support equipment. Existing Hanford Site cranes shall be used to install and remove the valve manifolds and cover blocks. However, new impact remote operated wrenches shall be provided to be used with the PUREX Connectors. No other new equipment or resources have been identified. However, if any special support equipment is identified during definitive design it shall be provided. An off-the-shelf commercially available pressure transmitter that will allow calibration of the transmitter without a pit entry shall be utilized.

\subsection{Critical Issues and Technologies}

The W-314 Transfer Piping System shall use existing technologies. No new technologies or unknowns have been identified.

\subsection{SUPPORT CONCEPT DESCRIPTION}

The equipment planned to be installed in support of the W-314 Transfer Piping System shall minimize the use of any specialized support equipment to keep the system operational throughout its design life. To the greatest extent possible, all equipment shall be Commercial Off-The-Shelf equipment which can function in the tank farm environment (i.e., radiological and chemical environments).

The constraints on maintainability will be the location of the equipment in contaminated areas. However, due 
to the type of equipment being installed, preventive maintenance requiring pit entry shall not be required for the design life of the equipment. The equipment in the pits shall be designed such that exposures during corrective maintenance will be ALARA. The installation and removal of equipment in the pits shall be performed remotely and if a component fails, it shall be replaced-in-kind. All like equipment (e.g., valves,

position sensors, leak detectors, pressure alarm systems, etc.) shall have interchangeable parts. The Hanford support infrastructure is set up to support these items.

The new cover blocks shall be equipped with at least three types of maintenance penetrations. One maintenance penetration shall be sized to support the installation and removal of the pit leak detector. The other maintenance penetrations shall be sized to support the installation and removal of equipment for pit inspections, gas sampling, and pit washdown. Enough inspection penetrations shall be provided to allow for visual inspection of the entire pit.

The accessible components of the transfer piping system, including leak detection systems, shall have a preventive maintenance frequency no less than annually .

The components of the jumper/valve manifold shall not require any preventive maintenance that requires pit entry.

The maximum time to repair the encasement and pit leak detection systems (excluding continuous leak detection system), excluding craft time to mobilize and enter tank farms, shall be equal to or less than 4 hours. Additionally, the encasement and pit leak detection system sensors shall be testable in place by the addition of water or by pressurizing the eneasement in the case of the slurry line (SLL-3160) encasement pressure alarm system.

\subsection{TRAINING CONCEPT DESCRIPTION}

The W-314 Transfer Piping System shall use technologies that are common at the Hanford Site. The design of the system shall be based on readily available commercial codes and standards. Therefore, it is not anticipated that any specialized training, course work, or special facilities need to be addressed during design of the transfer piping system.

\subsection{DEVELOPMENT CONCEPT DESCRIPTION}

No systems or components of the W-314 Transfer Piping System shall require proof-of-concept or development testing to confirm that the concepts can be translated into workable solutions.

\subsection{MANUFACTURING CONCEPT DESCRIPTION}

No specialized manufacturing processes, requirements, or constraints have been identified for the W-314 Transfer Piping System. 


\subsection{VERIFICATION CONCEPT DESCRIPTION}

The W-314 Transfer Piping System shall use readily available, commercial grade equipment, where possible, that complies with applicable codes and standards. Testing and inspection will be per the applicable Test and Evaluation Plan and the Quality Conformance Matrix contained in the PDS. For non-safety class structures, systems and components (SSCs), vendor invoices, commercial labels, and visual examination may be utilized upon receipt to verify components meet the identified requirements. No special test or validation procedures are anticipated. Specialized equipment or resources should not be required.

The only operational and maintenance testability features to be included in the design shall be the pressure I test risers to be installed on the encasement piping, and which provides the capability of testing the pit, low I point encasement and eneasement pressure buildup leak detection in place. All other validation and verification shall be by examination and shall not require any specialized equipment or resources.

\subsection{INSTALLATION AND START-UP DESCRIPTION}

The development of new or unique SSCs and technology is not planned for the W-314 Transfer Piping System. Test and acceptance procedures will be utilized as defined in the project Test and Evaluation Plan (TEP). These will include approved acceptance and operational test procedures (ATPs and OTPs). Start-up and turnover will be in accordance with current Operational Readiness and Acceptance for Beneficial Use $(A B U)$ procedures. No extraordinary requirements, special tools or equipment are anticipated to be necessary, and therefore will not restrain the design.

\subsection{SYSTEM DECONTAMINATION AND DECOMMISSIONING (D\&D)}

Before installation of new pit equipment, extensive decontamination to pits and removal of contaminated equipment for disposal may be required. D\&D activity, at closure, shall be minimal and shall consist of eventual disposal of the end-items and major components of the system upon decommissioning of the system.

The design of the W-314 Transfer Piping System shall consider measures that could be incorporated into the design for facilitating D\&D. The selection of materials and avoiding the trapping of waste in the components are the major design influences on D\&D. However, no special constraints on the design activities need to be addressed. 


\section{DISTRIBUTION SHEET}

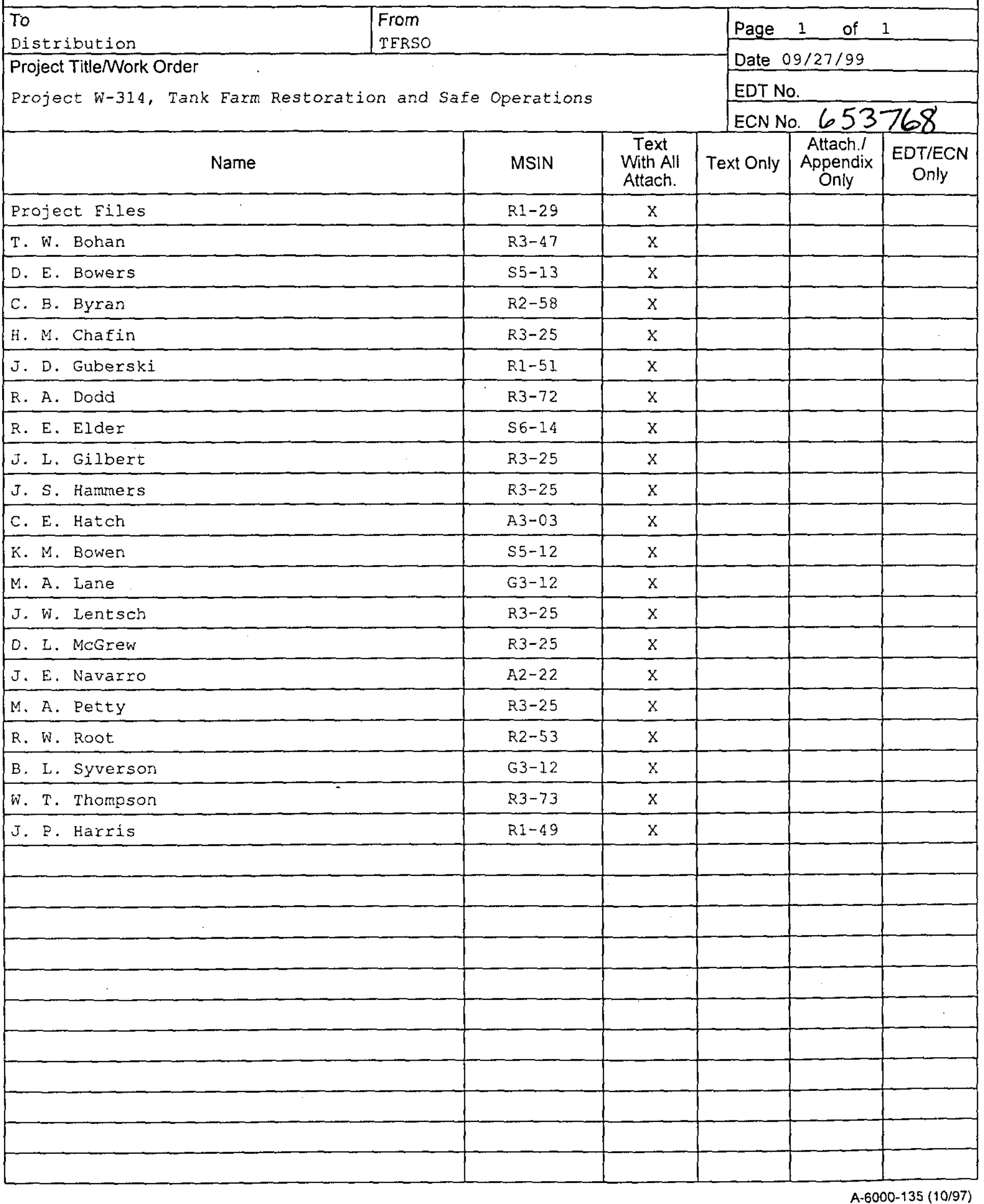

